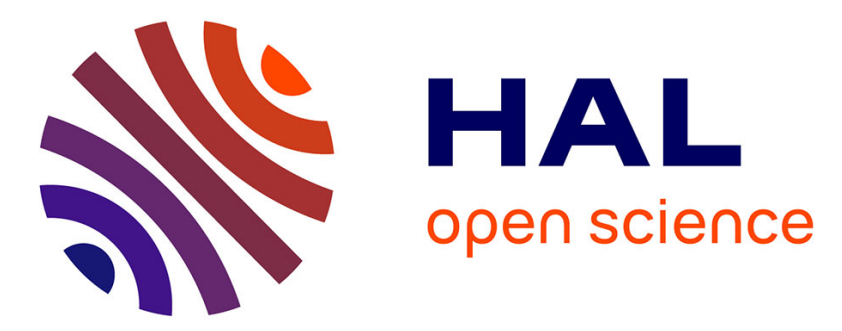

\title{
Annexin 1 is overexpressed and specifically secreted during experimentally induced colitis in rats
}

\author{
Nathalie Vergnolle, Christine Coméra, Lionel Bueno
}

\section{To cite this version:}

Nathalie Vergnolle, Christine Coméra, Lionel Bueno. Annexin 1 is overexpressed and specifically secreted during experimentally induced colitis in rats. European Journal of Biochemistry, 1995, 232, pp.603-610. hal-02705957

\section{HAL Id: hal-02705957 https://hal.inrae.fr/hal-02705957}

Submitted on 1 Jun 2020

HAL is a multi-disciplinary open access archive for the deposit and dissemination of scientific research documents, whether they are published or not. The documents may come from teaching and research institutions in France or abroad, or from public or private research centers.
L'archive ouverte pluridisciplinaire HAL, est destinée au dépôt et à la diffusion de documents scientifiques de niveau recherche, publiés ou non, émanant des établissements d'enseignement et de recherche français ou étrangers, des laboratoires publics ou privés. 


\title{
Annexin 1 is overexpressed and specifically secreted during experimentally induced colitis in rats
}

\author{
Nathalie VERGNOLLE, Christine COMÉRA and Lionel BUÉNO \\ Department of Pharmacology, Institut National de la Recherche Agronomique, Toulouse, France
}

(Received 30 March/20 June 1995) - EJB 95 0513/1

Annexin 1 is a protein induced by glucocorticoids endowed with extracellular anti-inflammatory properties. In this study, the local expression and secretion of annexins $1-6$, in rat proximal colon, were studied at different times after intracolonic administration of $30 \mathrm{mg}$ trinitrobenzenesulfonic acid in $50 \%$ ethanol. Secretion was identified by incubating colonic tissues in a culture medium. The expression of annexins was detected by immunoblotting in tissue homogenates and incubation media. Inflammatory stages were evaluated by measuring myeloperoxidase activity. Annexin 1 expression in colons increased after trinitrobenzenesulfonic acid treatment and was maximal between days 1 to 9 , during the cellular stage of the inflammation that corresponded to maximal myeloperoxidase activity. From $12 \mathrm{~h}$ to 9 days after trinitrobenzenesulfonic acid/ethanol treatment, annexin 1 was specifically secreted. Annexin 3 was also overexpressed during the cellular stage, but the expression of annexins $2,4,5$, and 6 was unchanged; none of these annexins were secreted. Annexin 1 was shown to be physiologically secreted because its release was specific, abundant, and not correlated with cellular lysis. Annexin 1 may be considered as a putative candidate in the control of the gut inflammatory processes.

Keywords: colitis; annexin 1; lipocortin 1; secretion; inflammation.

Glucocorticoids are the most effective anti-inflammatory drugs. They inhibit the expression of various proteins that enhance the production of mediators involved in inflammatory processes $[1-5]$. In the late 1970s, it was also shown that glucocorticoids stimulate both synthesis and secretion of an anti-inflammatory protein, named lipocortin [6]. Later on, this protein was found to be identical to annexin 1 (or lipocortin 1), which was purified and cloned in 1986 [7,8], and belongs to a family of homologous proteins known as annexins [9].

Annexin 1, or some of its fragments, has biological properties identical to those of lipocortin [9-11]. First, annexin 1 was shown to be synthethized or released in response to glucocorticoids although this is restricted to certain cells or tissues $[9,12-$ 17]. Secondly, it displays extracellular properties reproducing various glucocorticoid actions such as inhibition of the production of pro-inflammatory mediators both in vitro and in vivo [9-11, 18-26]. In this regard, in vitro studies showed that annexin 1 inhibits cellular phospholipase $\mathrm{A}_{2}\left(\mathrm{PLA}_{2}\right)$ and, consequently, the production of arachidonic acid, icosanoids, plateletactivating factor, and oxygen free radicals [18-21]. In vivo studies reported that natural or recombinant annexin 1, and some of its fragments, reduces inflammatory processes, icosanoid production and neutrophil migration when administered either locally or systemically $[9-11,13,22-26]$. In addition, in some models, local or systemic administration of antibodies directed

Correspondence to $\mathrm{C}$. Coméra, Department of Pharmacology, Institut National de la Recherche Agronomique, 180 chemin de Tournefeuille, BP 3, F-31931 Toulouse cedex, France

Fax: + 3361285310 .

Abbreviations. IL-1 $\beta$, interleukin- $1 \beta ; \quad \mathrm{N}_{3}$ ph- $\mathrm{SO}_{3} \mathrm{H}$, trinitrobenzenesulfonic acid; $\mathrm{PLA}_{2}$, phospholipase $\mathrm{A}_{2} ; \mathrm{LDH}$, lactate dehydrogenase; MPO, myeloperoxidase.

Enzymes. Phospholipase $\mathrm{A}_{2}$ (EC 3.1.1.4); lactate dehydrogenase (EC 1.1.1.27); myeloperoxidase (EC 1.11.1.7). to annexin 1 blocks the anti-inflammatory action of glucocorticoids or annexin 1, suggesting that annexin 1 is a natural mediator involved in glucocorticoid actions [24-26].

However, to exert a physiological extracellular anti-inflammatory action, annexin 1 should be secreted. The occurrence of such a secretion is subject to controversy [9]. First, it has been established that annexins are primarily intracellular proteins and are devoid of the signal peptide that is necessary in the conventional protein secretory pathway [9]. Secondly, annexin 1 and other annexins have been identified in extracellular locations, such as on cell surfaces, in cell culture media or in body fluids $[8,12-17,27-31]$. However, their low extracellular concentration led to the hypothesis that they were non-specifically released from damaged or dead cells rather than actually secreted. Nevertheless, the huge amount of annexin 1 detected in seminal plasma demonstrated a real secretion [29] and suggested that at least part of the annexins found in extracellular locations were probably secreted by a non-conventional secretory mechanism, as recently described for several other cytosolic proteins [32].

In addition, other annexins share similar properties with annexin 1. These properties include the inducibility of synthesis or secretion by glucocorticoids $[9,16]$ and anti-inflammatory properties in vitro or in vivo $[19,33,34]$. An overexpression of annexin 1 or other annexins has been reported in some pathological processes $[9,10,35-37]$. Annexin 1 was found to be downregulated in non-perforating Crohn's disease, whereas it was present at control levels in perforating Crohn's disease [38]. Nevertheless, neither the chronology of the appearance of annexin nor the occurrence of a real secretion with respect to inflammation has been well defined.

The aim of this work was therefore to determine whether an experimental colitis in the rat induces local expression and secretion of annexins and, if so, to investigate this phenomenon in relation to the time course of the inflammatory response. 


\section{MATERIALS AND METHODS}

Animal preparation and colitis induction. Colitis induction on the proximal colon was adapted from the model of rectocolitis previously described by Morris et al. [39]. 103 male Wistar rats weighing $225-300 \mathrm{~g}$ were used. After an overnight fast, rats were anesthetized by intraperitoneal injection of $0.5 \mathrm{mg} / \mathrm{kg}$ acepromazine and $100 \mathrm{mg} / \mathrm{kg}$ ketamine (Imalgene 1000, Rhône-Mérieux). The early effects of trinitrobenzenesulfonic acid $\left(\mathrm{N}_{3} \mathrm{ph}-\mathrm{SO}_{3} \mathrm{H}\right) /$ ethanol were studied in 31 conscious animals. They were fitted with a polyethylene catheter $(0.9 \mathrm{~mm}$ in external diameter) inserted into the proximal colon $1 \mathrm{~cm}$ from the cecocolonic junction and exteriorized at the back of the neck. Five days later, the animals were fasted overnight and received $0.3 \mathrm{ml} \mathrm{N} \mathrm{ph}_{3} \mathrm{SO}_{3} \mathrm{H}(30 \mathrm{mg}$ ) in $50 \%$ ethanol in the proximal colon, through the catheter. The animals were sacrificed $4,8,12$, 16,20 or $24 \mathrm{~h}$ after the treatment; four rats were used each time except for the time points $12 \mathrm{~h}$ and $16 \mathrm{~h}$ where eight and three rats were treated, respectively. The remaining rats were used for the study of later effects of $\mathrm{N}_{3} \mathrm{ph}-\mathrm{SO}_{3} \mathrm{H} /$ ethanol. They were fasted overnight, anesthetized and received the same $\mathrm{N}_{3}$ ph$\mathrm{SO}_{3} \mathrm{H} /$ ethanol treatment by direct injection into the proximal colonic lumen. They were sacrificed $1,3,6,9,12,15,18$ or 21 days later (eight rats for each time-point). The control animals fitted with a catheter received $0.3 \mathrm{ml}$ saline $(0.9 \% \mathrm{NaCl})$ and were sacrificed $24 \mathrm{~h}$ later while the other control animals were sacrificed 6 days later the $0.3 \mathrm{ml}$ injection of saline. 1 day after the $\mathrm{N}_{3}$ ph-SO $\mathrm{SO}_{3} \mathrm{H} /$ ethanol treatment, no difference was observed between the two modes of administration for all the parameters considered.

Preparation of tissue samples. Animals were sacrificed by cervical dislocation and proximal colons were rapidly collected and rinsed with saline. Colons were cut into equivalent pieces to study either myeloperoxidase (MPO) activity or annexin expression and secretion. MPO activity and annexin expression were determined in all the tissues obtained. Secretion experiments were studied for eight proximal colons from control rats and from animals sacrified at $12 \mathrm{~h}$ and on days $1-21$ after the $\mathrm{N}_{3}$ ph-SO $\mathrm{S}_{3} \mathrm{H} / \mathrm{eth}$ anol treatment.

Study of annexin expression. Freshly isolated proximal colons were homogenized using a Polytron for $30 \mathrm{~s}$ at $0^{\circ} \mathrm{C}$ and sonicated for $30 \mathrm{~s}$ at $0^{\circ} \mathrm{C}$ in a lysis buffer, containing $25 \mathrm{mM}$ Tris/ $\mathrm{HCl}, \mathrm{pH} 7.4,5 \mathrm{mM}$ EDTA, $0.25 \%$ (by vol.) Nonidet P-40, $1 \mu \mathrm{g} / \mathrm{ml}$ pepstatin, $15 \mu \mathrm{g} / \mathrm{ml}$ benzamidine, $1 \mu \mathrm{g} / \mathrm{ml}$ antipain, $1 \mu \mathrm{g} / \mathrm{ml}$ leupeptin, $1000 \mathrm{IU} / \mathrm{ml}$ aprotinin and $4 \mathrm{mM}$ phenylmethylsulfonyl fluoride. Homogenates were equilibrated in an electrophoresis sample buffer $[60 \mathrm{mM}$ Tris $/ \mathrm{HCl}, \mathrm{pH} 6.8,10 \%$ (by vol.) glycerol, 5\% (by vol.) 2-mercaptoethanol, $2 \%$ (mass/vol.) sodium dodecyl sulfate (SDS), $0.01 \%$ (mass/vol.) bromophenol blue], boiled for $5 \mathrm{~min}$, and stored at $-80^{\circ} \mathrm{C}$. Protein concentrations were measured according to Bradford [40].

Study of annexin secretion. Annexin secretion was studied by washing colonic fragments followed by incubation in cell culture medium. Tissue washes were performed on ice, to block secretory processes, and in the presence of $2 \mathrm{mM}$ EGTA, to remove potential extracellular annexins that could be bound to the cell surface by calcium-dependent interaction. Proximal colonic tissues were cut into small pieces and washed four times for $20 \mathrm{~min}$ in $\mathrm{NaCl} / \mathrm{P}_{\mathrm{i}}(150 \mathrm{mM} \mathrm{NaCl}, 2.5 \mathrm{mM} \mathrm{KCl}, 10 \mathrm{mM}$ $\mathrm{Na}_{2} \mathrm{HPO}_{4}, 1.5 \mathrm{mM} \mathrm{KH} \mathrm{PO}_{4}, \mathrm{pH} 7.4$ ) three times in the presence of $2 \mathrm{mM}$ EGTA and one time without EGTA. Thereafter, tissue incubation was performed following two stages, in a culture medium [RPMI 1640 (Eurobio) plus $1 \mathrm{mM}$ glutamine, $0.02 \mathrm{mM}$ EGTA, $20 \mathrm{mM}$ Hepes, pH 7.4]. First, colons were incubated for $30 \mathrm{~min}$ at $37^{\circ} \mathrm{C}$ to allow protein secretion. Secondly, samples were adjusted to $2 \mathrm{mM}$ final EGTA, rapidly cooled to $0^{\circ} \mathrm{C}$, and further incubated for a 15-min period on ice, allowing extracellular annexins to be released into the media. After either washes or incubations, tissues were separated from supernatants, homogenized in the lysis buffer, and subsequently equilibrated in the electrophoresis sample buffer as previously described. Supernatants were centrifuged at $13000 \times g$ for $20 \mathrm{~s}$, to eliminate cells or tissue fragments. Supernatant proteins were precipitated by a 10 -min incubation on ice with $10 \%$ (mass/vol.) trichloroacetic acid (final concentration), centrifuged at $13000 \times \mathrm{g}$ for $10 \mathrm{~min}$, suspended in the electrophoresis sample buffer, boiled for $5 \mathrm{~min}$, and stored at $-80^{\circ} \mathrm{C}$. Aliquots of homogenates in the lysis buffer and fresh supernatants were kept at $4{ }^{\circ} \mathrm{C}$ to measure lactacte dehydrogenase (LDH) activity.

Study of the annexin 1 extracellular form. Two secretion experiments were modified to establish if annexin 1 in the culture medium was in a soluble form. After the 20 -s centrifugation at $13000 \times \mathrm{g}$, to eliminate cells or tissue fragments, culture supernatants were supplemented with protease inhibitors $(1 \mu \mathrm{g} /$ $\mathrm{ml}$ pepstatin, $15 \mu \mathrm{g} / \mathrm{ml}$ benzamidine, $1 \mu \mathrm{g} / \mathrm{ml}$ antipain, $1 \mu \mathrm{g} / \mathrm{ml}$ leupeptin, $1000 \mathrm{IU} / \mathrm{ml}$ aprotinin, and $4 \mathrm{mM}$ phenylmethylsulfonyl fluoride; final concentrations). Samples were centrifuged for $2 \mathrm{~h}$ at $100000 \times \mathrm{g}$. Pellets, containing the vesicular protein fraction, were resuspended in the electrophoresis sample buffer; supernatant soluble proteins were precipitated as described above and resuspended in the electrophoresis sample buffer.

Detection of annexins by SDS/PAGE and immunoblotting. Proteins from homogenate and supernatant samples equilibrated in the sample buffer were separated by SDS/PAGE in $10 \%$ polyacrylamide gels according to Laemmli [41], and electrophoretically transferred onto nitrocellulose membranes as described by Towbin et al. [42] in $25 \mathrm{mM}$ Tris/ $\mathrm{HCl}, 192 \mathrm{mM}$ glycine, $0.01 \%$ (by vol.) SDS, $15 \%$ methanol. Immunoblottings were performed using different monospecific rabbit polyclonal antibodies. Antibodies were specific to either annexins 1, 3 or 6 [used at $1: 1000,1: 100$ and $1: 1000$ dilutions, respectively, a gift from F. Russo-Marie, Institut National de la Santé et de la Recherche Médicale (INSERM) U332, Paris, France], to annexin 1 or 2 from (both used at 1:1000, provided by L. A Pradel, Centre National de la Recherche Scientifique UA 1112, Paris, France), to annexin 1 or 5 (both used at 1:500, provided by $H$. Chap, INSERM U326, Toulouse, France), to annexin 4 (used at $1: 250$, from C. E. Creutz, Charlottesville, USA) and to annexin 2 (used at $1: 1000$, a gift from J. C. Cavadore, INSERM U249, Montpellier, France). All the antibodies used were tested for their monospecificity by immunoblotting with pure annexins $1-6$ (gifts from F. Russo-Marie) and different cell and tissue homogenates. Immunoblottings for annexin 1 detection were performed with polyclonal antibodies affinity purified on a human recombinant annexin-1-Sepharose 4B column kindly provided by F. Russo-Marie and J. F. Browning for the recombinant annexin 1 (Biogen Corp.). Incubations were performed in buffer A $(25 \mathrm{mM}$ Tris/ $\mathrm{HCl}, \mathrm{pH} 7.4,150 \mathrm{mM} \mathrm{NaCl}, 0.1 \%$ Tween-20) for $1 \mathrm{~h}$ with $5 \%$ dried milk, to saturate non-specific binding sites, followed by $1 \mathrm{~h}$ in the presence of anti-annexin antibodies. Nitrocellulose sheets were then washed five times for $5 \mathrm{~min}$ in buffer $\mathrm{A}$, incubated for $30 \mathrm{~min}$ in the presence of anti-rabbit antibodies made by goat and linked to horseradish-peroxidase (1:10000 dilution, Sigma) and washed three times for $5 \mathrm{~min}$ in buffer A. Immunolabeled bands were revealed by fluorography, using the ECL reagents (Enhanced Chemiluminescence, Amersham) followed by exposure from $1 \mathrm{~min}$ to $1 \mathrm{~h}$ to Hyperfilm MP (Amersham). For densitometric quantifications, films were preflashed before exposure for $1 \mathrm{~ms}$ with a Sensitize pre-flash unit (Amersham). 
Densitometric quantification of annexin 1 secretion. The extracellular and intracellular contents of annexin 1 from secretion studies were assessed by SDS/PAGE and immunoblotting using different dilutions of both homogenates and supernatants and different concentrations of pure human annexin 1 (from $\mathrm{F}$. Russo-Marie). To quantify annexin 1 contents, densitometric scans of the fluorographs were performed with a Shimadzu CS930 chromoscan (Kyoto, Japan) with a linear correlation between densitometric values and the amounts of annexin 1 for 20-100 ng. The percentage of extracellular annexin 1 was calculated by dividing the amount detected in supernatants $(38 \mathrm{kDa}$ and $33 \mathrm{kDa}$ ) by the sum of the amount detected in supernatants and homogenates multiplied by 100 .

Measurement of cellular lysis. Cell viability was determined by spectrophotometric measurement of LDH activities as described by Bergmeyer and Bernt [43], in both fresh supernatants and tissue homogenates from the secretion experiments. The percentage of cellular lysis is equivalent to the percentage of LDH released into supernatants and was calculated by dividing the activity detected in supernatants by the sum of the activities detected in supernatants and in tissue homogenates multiplied by 100 .

Measurement of MPO activity. Proximal colonic tissues were homogenized twice for $30 \mathrm{~s}$ and sonicated three times for $30 \mathrm{~s}$ at $0{ }^{\circ} \mathrm{C}$ in $0.5 \%$ hexadecyltrimethylammonium bromide in $50 \mathrm{mM}$ sodium phosphate, pH 6.0, according to Bradley et al. [44]. The homogenates were clarified by centrifugation at $13000 \times \mathrm{g}$ for $15 \mathrm{~min}$, at $4^{\circ} \mathrm{C}$, and were assessed for MPO activity in $3 \mathrm{ml} 50 \mathrm{mM}$ sodium phosphate, $\mathrm{pH} 6.0$, containing $16 \mathrm{mM}$ aqueous guaiacol and $5.9 \mathrm{mM} \mathrm{H}_{2} \mathrm{O}_{2}$ as previously described [45]. The increase in absorbance was measured for $2 \mathrm{~min}$ at $470 \mathrm{~nm}$ using a Uvikon 860 spectrophotometer (Kontron Instruments). Protein concentrations were determined using the BioRad DC protein assay. MPO activities were expressed in $\mathrm{U} / \mathrm{mg}$ protein with $1 \mathrm{U}$ hydrolyzing $1 \mu \mathrm{mol} \mathrm{H}_{2} \mathrm{O}_{2} /$ min.

Statistics. Statistics were established using a one-way analysis of variance followed by the Student's $t$ test. Differences were considered significant for $P$ values $\leqslant 0.05$.

\section{RESULTS}

Kinetics of tissue damage and MPO activities. During the first $24 \mathrm{~h}$ following $\mathrm{N}_{3}$ ph-SO $\mathrm{SO}_{3} \mathrm{H} /$ ethanol treatment, mucosa had a continuous yellow to dark orange colour from $4 \mathrm{~h}$ after treatment, and a hyperemia that increased up to $24 \mathrm{~h}$. From 1 to 6 days after $\mathrm{N}_{3}$ ph-SO $\mathrm{S}_{3} \mathrm{H} /$ ethanol administration, proximal colons showed a strong inflammation with at least $80 \%$ of mucosal necrosis over $1-5 \mathrm{~cm}$, a dark red to brown colour, and apparent hyperemia and ulcers. On day 9, necrotic tissues were dissociated from the bowel wall by slabs and recovered in distal colonic contents. At days 12-21 after $\mathrm{N}_{3}$ ph-SO $\mathrm{SO}_{3} \mathrm{H} /$ ethanol treatment, no more necrotic tissues were present. The wall thickness increased from day 3 to, at least, day 12 , followed by a gradual decrease. However, the colonic diameter remained larger than in the control rats until day 21 after treatment. No bowel perforation was found at any time.

MPO activity of the tissues increased from days 1-9 after $\mathrm{N}_{3}$ ph- $\mathrm{SO}_{3} \mathrm{H} / \mathrm{ethanol}$ administration, with a factor in the range 15-26 compared to control values (Fig. 1). From days 12-21, this activity decreased rapidly. All values were significantly different from control values $(P<0.05)$ except at day 21 . Maximal MPO activities corresponded to the cellular stage of inflammation with the presence of numerous leukocytes.

Annexin expression. Annexin 1 expression in the proximal colon was increased from $4 \mathrm{~h}$ to 21 days after $\mathrm{N}_{3}$ ph- $\mathrm{SO}_{3} \mathrm{H} / \mathrm{ethanol}$

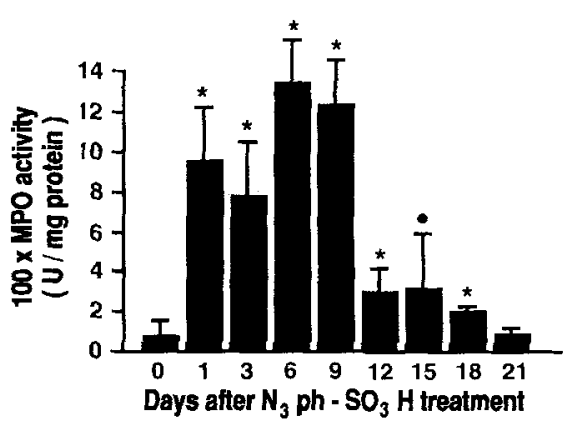

Fig. 1. Effect of $\mathrm{N}_{3} \mathrm{ph}-\mathrm{SO}_{3} \mathrm{H} /$ ethanol treatment on MPO activity in proximal colon tissues : a time course study. MPO activity in colonic homogenates was determined by spectrophotometric measurement and expressed in $\mathrm{U} / \mathrm{mg}$ protein with $1 \mathrm{U}$ hydrolyzing $1 \mu \mathrm{mol} \mathrm{H}_{2} \mathrm{O}_{2} / \mathrm{min}$. The time labeled 0 corresponds to control rats. Data are expressed as means $\pm \mathrm{SD}$ with $n=8$ for each time. Compared to controls, values are significantly increased (* for $P \leqslant 0.001$ and $\bullet$ for $P \leqslant 0.005$ ) at any time after $\mathrm{N}_{3} \mathrm{ph}-\mathrm{SO}_{3} \mathrm{H} / \mathrm{ethanol}$ treatment except on day 21 .

treatment with maximal levels at $1-9$ days post-treatment (Fig. 2A and B). From $12 \mathrm{~h}$ until day 6, colonic annexin 1 was always expressed in two forms: the major one had an apparent molecular mass of $38 \mathrm{kDa}$ and corresponded to the intact protein, the minor one migrated slightly faster at $33 \mathrm{kDa}$. The two forms of annexin 1 were also detected occasionally at $8 \mathrm{~h}$ posttreatment (one animal out of four) and at day 9 (four animals out of eight). All the other colonic homogenates expressed only the $38-\mathrm{kDa}$ form of annexin 1 . These two forms were confirmed to be annexin 1 because they were both recognized by monospecific anti-annexin 1 polyclonal antibodies from different sources. Moreover, the $38-\mathrm{kD}$ a protein was recognized by a monoclonal antibody directed to the $\mathrm{N}$-terminal end of human annexin 1 (Zymed; data not shown). Annexin 3 expression was also increased during $\mathrm{N}_{3}$ ph-SO $\mathrm{SO}_{3} \mathrm{H} /$ ethanol-induced inflammation, especially at days 3-9 post-treatment (Fig. 2B). In contrast, colonic expression of annexins 2 and 6 was similar to that of the control rats throughout the time period after $\mathrm{N}_{3}$ ph- $\mathrm{SO}_{3} \mathrm{H} / \mathrm{ethanol}$ administration (Fig. 2B). Annexins 4 and 5 were not detected in any colonic homogenate.

Annexin secretion. Supernatants from incubated tissues obtained from rats at $12 \mathrm{~h}$ to 6 days after $\mathrm{N}_{3}$ ph-SO $\mathrm{SO}_{3} \mathrm{H} / \mathrm{ethanol}$ treatment contained annexin 1 (Fig. $3 \mathrm{~A}$, not shown for $12 \mathrm{~h}$ ). At day 9 , four of the eight tissues tested released this protein. Annexin 1 was not found in supernatants of colonic tissues from controls or in treated rats from days $12-21$, even after extensive film exposure. All the tissues that expressed the two forms of annexin 1 in homogenates from freshly isolated colons, released the protein in these two forms when incubated in the RPMI medium (Figs 2 and 3). Annexins 2, 3 and 6, which are expressed in proximal colons, were not found in supernatants (Fig. 3 B). When tissues that expressed the two forms of annexin 1 were washed (three times for $20 \mathrm{~min}$ in $\mathrm{NaCl} / \mathrm{P}_{\mathrm{i}}$ plus $2 \mathrm{mM} \mathrm{EGTA}$ ), or washed the same way and incubated in RPMI medium (for $30 \mathrm{~min}$ at $37^{\circ} \mathrm{C}$ followed by $15 \mathrm{~min}$ at $0^{\circ} \mathrm{C}$ in the presence of $2 \mathrm{mM}$ EGTA), the whole $33-\mathrm{kDa}$ protein and part of the $38-\mathrm{kDa}$ annexin 1 were recovered in supernatants. The corresponding colonic homogenates contained only the $38-\mathrm{kDa}$ protein (Fig. 4). Extraction from the tissues of both annexin 1 forms required the presence of $2 \mathrm{mM}$ EGTA (data not shown).

To determine if the release of annexin 1 is due to a physiological secretion, the amounts of annexin 1 present in both homogenates and supernatants were quantified by immunoblotting and densitometric analysis for four samples from either control 
A

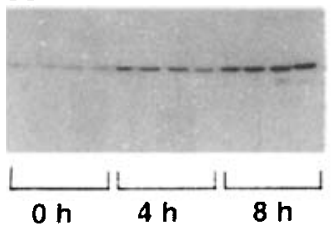

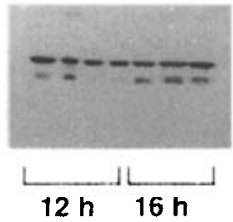

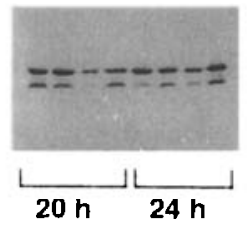

An 138 kDa

An $133 \mathrm{kDa}$

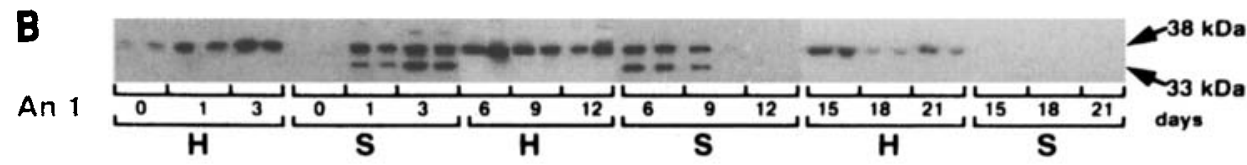

An 2

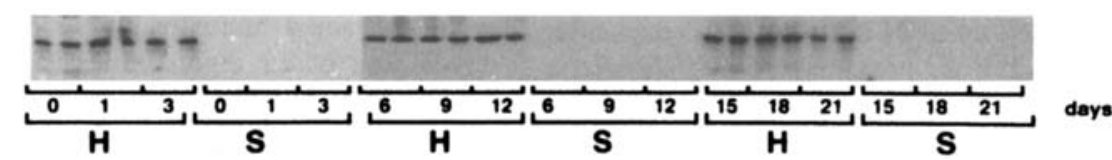

An 3

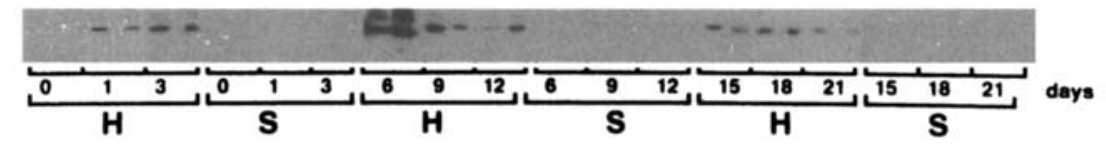

An 6
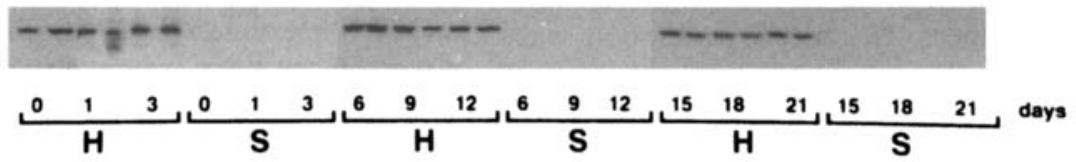

Fig. 2. Immunoblotting analysis of the annexin expression in homogenates of freshly isolated proximal colons at different times after $\mathrm{N}_{3}$ ph-SO $\mathbf{S}_{3} \mathrm{H} /$ ethanol administration. (A) Early effect of $\mathrm{N}_{3} \mathrm{ph}_{-} \mathrm{SO}_{3} \mathrm{H} /$ ethanol on the annexin 1 expression. Colons were recovered at 0 (control rats), $4,8,12,16,20$ and $24 \mathrm{~h}$ after treatment. (B) Late effects of $\mathrm{N}_{3} \mathrm{ph}-\mathrm{SO}_{3} \mathrm{H} /$ ethanol on the expression of annexins 1 (An 1), 2 (An 2), 3 (An 3), and 6 (An 6) expression. Colons were isolated at 0 (control rats), 1, 3, 6, 9, 12, 15, 18 and 21 days after treatment. Equivalent amounts of proteins were loaded for each sample. The expressions of annexins 1 and 3 are increased by $\mathrm{N}_{3} \mathrm{ph}-\mathrm{SO}_{3} \mathrm{H} / \mathrm{ethanol}$ treatment with a maximum from days 1-9 after administration. The expressions of annexins 2 and 6 remain similar at any time.

An 1

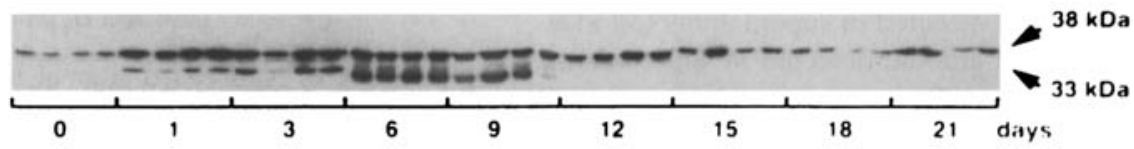

An 2

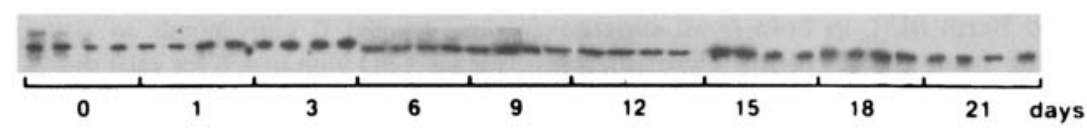

An 3

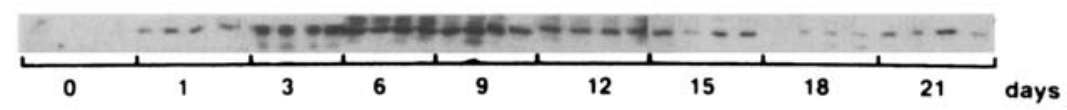

An 6

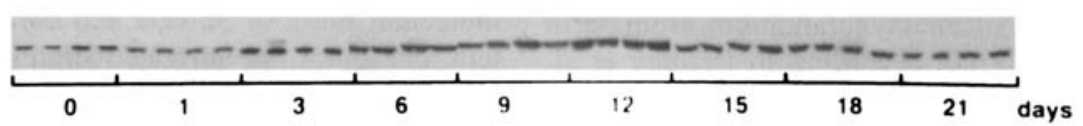

Fig. 3. Immunoblotting analysis of annexin secretion by proximal colons during incubation in RPMI medium. Tissues were isolated at different times after $\mathrm{N}_{3}$ ph-SO $\mathrm{SO}_{3} \mathrm{H}$ /ethanol administration ( 0 for control rats, $1,3,6,9,12,15,18$ and 21 days) and washed (four washes of $20 \mathrm{~min}$ in $\mathrm{NaCl}$ / $P_{i}$ : three times with $2 \mathrm{mM}$ final EGTA and subsequently once without EGTA). Thereafter, tissues were incubated in RPMI medium for 30 min at $37^{\circ} \mathrm{C}$ followed by $15 \mathrm{~min}$ at $0^{\circ} \mathrm{C}$ after adding $2 \mathrm{mM}$ final EGTA. The presence of annexin 1 (An 1), 2 (An 2), 3 (An 3), and 6 (An 6) is detected by immunoblotting in homogenates $(\mathrm{H})$ and supernatants (S) after RPMI incubation. Equivalent amounts of homogenate proteins were used for each sample. Supernatant volumes loaded represent five times those of the corresponding homogenates. Annexin 1 is the only one of the annexins detected in the colon that is released into the medium. Its release occurs selectively at days 1,3,6, and 9 after $\mathrm{N}_{3} \mathrm{ph}_{-} \mathrm{SO}_{3} \mathrm{H} / \mathrm{ethanol}$ treatment. 
$\mathrm{kDa}$

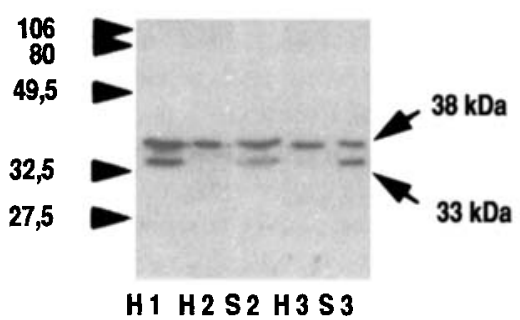

Fig. 4. Immunoblotting analysis of annexin 1 extraction from one proximal colon isolated 1 day after $\mathrm{N}_{3} \mathrm{ph}-\mathrm{SO}_{3} \mathrm{H} / \mathrm{ethanol}$ administration. $\mathrm{H} 1$, homogenate of freshly isolated colon; $\mathrm{H} 2$ and $\mathrm{S} 2$, homogenate and pooled supernatants, respectively of colon washes (four washes of $20 \mathrm{~min}$ in $\mathrm{NaCl} / \mathrm{P}_{\mathrm{i}}$ : three times with $2 \mathrm{mM}$ final EGTA and subsequently once without EGTA); H3 and S3, homogenate and supernatant, respectively, of colon incubation in RPMI (tissue was washed as previously described, subsequently incubated in RPMI medium for 30 min at $37^{\circ} \mathrm{C}$ followed by $15 \mathrm{~min}$ at $0^{\circ} \mathrm{C}$ and in the presence of $2 \mathrm{mM}$ final EGTA). Equivalent amounts of proteins were loaded for all homogenates; S2 and $\mathrm{S} 3$ volumes loaded represent two and five times more than $\mathrm{H} 2$ and $\mathrm{H} 3$ volumes, respectively. Migration positions of molecular mass standards are noted on the left $(\mathrm{kDa})$. The whole $33-\mathrm{kDa}$ form and part of the $38-\mathrm{kDa}$ form of annexin 1 , which are expressed in the freshly isolated tissue $(\mathrm{H} 1)$, can be removed in supernatants $\mathrm{S} 2$ and $\mathrm{S} 3$ in the presence of 2 mM EGTA.

animals or rats after $1,3,6$ or 9 days of $\mathrm{N}_{3}$ ph- $\mathrm{SO}_{3} \mathrm{H} / \mathrm{ethanol}$ colonic administration (Table 1). The results are expressed as amounts of intracellular annexin 1 (present in homogenates) and as percentages of extracellular annexin 1 . The latter were compared to the percentage of cell lysis. Whereas all tissues displayed identical cell lysis, which remained inferior to $5.5 \%$ at all the times tested, the percentage of extracellular annexin 1 increased up to $24.4 \%$ on day 3 (Table 1). Moreover, there was no correlation between the percentage of cell lysis and the percentage of extracellular annexin $1(r=0.109, n=8)$. The percentage of extracellular annexin 1 released by rat proximal colons varied with time after $\mathrm{N}_{3} \mathrm{ph}-\mathrm{SO}_{3} \mathrm{H} /$ ethanol administration. It increased from days $1-3(P<0.01)$, and subsequently decreased on days 6 and 9 . On days $1-6, \mathrm{~N}_{3} \mathrm{ph}-\mathrm{SO}_{3} \mathrm{H} / \mathrm{ethanol}$ treatment increased annexin 1 intracellular expression up to $25-$ 36 times compared to initial values. On day 6 , it reached a mean value as high as $7.5 \%$ of the total protein, which is much more than the previously estimated cellular contents of this protein $[8,46]$.

The extracellular form of annexin 1. After centrifugation of culture media for $2 \mathrm{~h}$ at $100000 \times \mathrm{g}$, the pellets contained vesicular proteins, whereas the soluble proteins remained in the supernatants. As detected (Fig. 5) and quantified by immunoblotting, $30 \%$ of the total secreted annexin 1 was found in the pellets, in the $38-\mathrm{kDa}$ form. Supernatants contained the two forms of soluble annexin $1(33 \mathrm{kDa}$ and $38 \mathrm{kDa})$, which constituted $70 \%$ of the total secreted protein.

\section{DISCUSSION}

As a main conclusion, our study shows that annexins 1 and 3 , but not annexins $2,4,5$, and 6 , are overexpressed during $\mathrm{N}_{3} \mathrm{ph}_{-} \mathrm{SO}_{3} \mathrm{H} / \mathrm{ethanol}$-induced rat colitis. Moreover, annexin 1 appears to be selectively secreted during the cellular stage of the colitis. In this model, proximal colons exhibit significantly high levels of MPO activity until day 9, and these high levels corre-
Table 1. Time course comparison of the amounts of intracellular annexin 1, extracellular annexin 1 and cellular lysis during secretion experiments. The amounts of intracellular annexin 1 and the percentages of extracellular annexin 1 were determined by densitometric quantification after immunoblotting in supernatants and colonic homogenates obtained from secretion experiments. Annexin 1 amounts were calculated as $\mathrm{ng} / \mu \mathrm{g}$ total proteins in homogenates. The percentage of extracellular annexin 1 was calculated from the amounts of extracellular (present in supernatants) and intracellular (present in the corresponding homogenates) annexin 1 . The percentage of cellular lysis was estimated by LDH activity measurement in homogenates and supernatants. Data are expressed as the mean $\pm S \mathrm{SD}(n=4)$. This experimental colitis increases annexin 1 intracellular expression and release, with no correlation between the percentage of extracellular annexin 1 and the percentage of cellular lysis.

\begin{tabular}{|c|c|c|c|}
\hline $\begin{array}{l}\text { Time after } \\
\mathrm{N}_{3} \mathrm{ph}-\mathrm{SO}_{3} \mathrm{H} \\
\text { treatment }\end{array}$ & $\begin{array}{l}\text { Intracellular } \\
\text { annexin } 1\end{array}$ & $\begin{array}{l}\text { Extracellular } \\
\text { annexin } 1\end{array}$ & $\begin{array}{l}\text { Cellular } \\
\text { lysis }\end{array}$ \\
\hline days & $\mathrm{ng} / \mu \mathrm{g}$ total protein & $\%$ & \\
\hline 0 (control) & $2.1 \pm 0.8$ & not detected & $5.1 \pm 1.3$ \\
\hline 1 & $53.9 \pm 23.0^{\mathrm{a}}$ & $11.7 \pm 3.2$ & $4.9 \pm 0.7$ \\
\hline 3 & $59.6 \pm 37.4^{\mathrm{a}}$ & $24.4 \pm 5.6$ & $5.4 \pm 0.4$ \\
\hline 6 & $75.4 \pm 35.0^{a}$ & $18.5 \pm 3.7$ & $4.4 \pm 1.7$ \\
\hline 9 & $29.8 \pm 20.9^{a}$ & $12.4 \pm 4.8$ & $5.3 \pm 1.3$ \\
\hline
\end{tabular}

"Values significantly different from control $(P \leqslant 0.003)$.

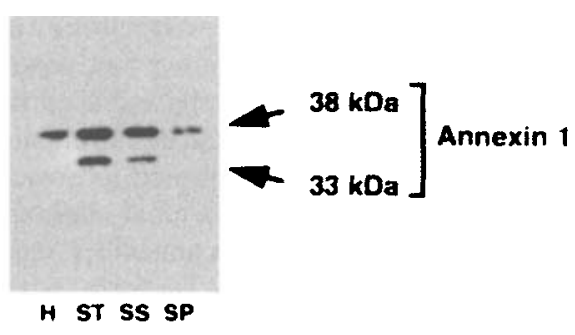

Fig. 5. Immunoblotting analysis of the annexin 1 extracellular form in one proximal colon isolated 1 day after $\mathrm{N}_{3}$ ph-SO $\mathrm{S}$ /ethanol administration. $\mathrm{H}$ and ST, homogenate and total supernatant, respectively, of colon incubation in RPMI as previously described. SS, supernatant of colon incubation in RPMI after a 2-h centrifugation at $100000 \times g$; SP, pellet of colon incubation in RPMI after a 2-h centrifugation at $100000 \times g$. The volume loaded for each supernatant represents five times the volume of the homogenate. The whole $33-\mathrm{kDa}$ form and the major part of the $38-\mathrm{kDa}$ form of annexin 1 were detected in soluble forms in the supernatant of the colon incubation in RPMI after a highspeed centrifugation; a minor part of the $38-\mathrm{kDa}$ form was found in the pellet.

spond to the presence of necrotic mucosa. Subsequently, MPO activities decreased rapidly, from day 12 until day 21 after $N_{3}$ ph$\mathrm{SO}_{3} \mathrm{H}$ treatment. The activities were significantly different from control values except at day 21 . This rapid recovery of normal MPO values after $\mathrm{N}_{3}$ ph-SO $\mathrm{S}_{3} \mathrm{H} / \mathrm{ethanol}$ administration differs from the findings of several reports $[39,47]$ although one study reached an identical conclusion [48].

Other investigators previously reported a local increase of the expression of either annexin 1 alone, or various annexins, in pathological conditions $[9,10,35-37]$. For instance, annexin 1 overexpression has been detected in resident keratinocytes from thick skins, or in reactive astrocytes that migrate in kainatelesioned rat cerebellum $[36,37]$. In addition, annexins 1 and 3 were reported to be abundant in inflammatory leukocytes such 
as macrophages (annexin 1) [13] and neutrophils (annexins 1 and 3) $[49,50]$. In our model, the maximal expression of both annexins 1 and 3 occurs during the cellular inflammatory stage, corresponding to maximal MPO activities. This suggests that such overexpressions may be attributed, at least in part, to local leukocyte invasion of inflamed colons, but the cells overexpressing annexin 1 in this colitis remain to be identified.

This experimental colitis induces intracellular expression of both annexins 1 and 3, but the concept that annexins can have an intracellular anti-inflammatory activity is a subject of controversy [9]. Among the various hypotheses put forward for the intracellular role of annexins, an action in secretory processes and in signal transduction, including PLA ${ }_{2}$ activation, has been proposed $[9,50,51]$. However, the pathophysiological consequence of annexin intracellular overexpression during inflammation is still unknown.

In contrast, the extracellular anti-inflammatory properties of annexins are well documented [9-11]. Our results show that annexin 1 is specifically released into the medium of the incubated colon during the cellular stage of colitis. Two forms of annexin $1(38 \mathrm{kDa}$ and $33 \mathrm{kDa})$ were detected in inflamed colonic tissues. Only part of the $38-\mathrm{kDa}$ annexin 1 was extracted from colons, and extensive washes with longer incubation times or higher EGTA concentrations did not improve its release (data not shown). This suggests that part of the $38-\mathrm{kDa}$ protein is extracellular because it can be removed from tissues by chelating calcium ions. The non-extractible part is presumed to remain intracellular. The 33-kDa fragment of annexin 1 was completely removable from tissues by washes in the presence of $2 \mathrm{mM}$ EGTA, indicating an exclusively extracellular location. In agreement with our results, it was shown that annexin 1 has a molecular mass of $38 \mathrm{kDa}$ inside the cells and is partially proteolyzed at its N-terminal end, in the extracellular medium [12, 17, 28, 29]. Such a degradation was suggested to downregulate its anti-inflammatory activity [28]. Monoclonal antibodies directed against the $\mathrm{N}$-terminal part of human annexin 1 recognized the $38-\mathrm{kDa}$ rat annexin 1 but not the 33-kDa form, whereas all the polyclonal antibodies tested recognized both forms. This observation strongly suggests that the $33-\mathrm{kDa}$ annexin 1 is a fragment lacking the N-terminus. Moreover, our results support the finding that proteolysis occurs in the extracellular milieu, on the soluble $38-\mathrm{kDa}$ annexin 1 . Indeed, after a high-speed centrifugation of culture medium, the $33-\mathrm{kDa}$ form is detected in supernatants, but not in pellets.

Our study supports the view that annexin 1 is also secreted in vivo. The colonic expression of both $33-\mathrm{kDa}$ and $38-\mathrm{kDa}$ annexin 1 in freshly isolated homogenates was restricted to tissues that release annexin 1 in secretion experiments. The fact that extracellular $33-\mathrm{kDa}$ annexin 1 was completely removed from tissues upon washing with EGTA prior to incubation in RPMI, leads to the conclusion that annexin 1 was further secreted into the medium during this in vitro incubation. Moreover, several observations suggest that annexin 1 release in RPMI medium is a physiological secretion by living cells: (a) this release is specific for annexin 1 since we never detected annexins 2, 3 and 6 in the medium; (b) the percentage of cell lysis is identical whether annexin 1 is released or not; (c) the large amounts of annexin 1 found in supernatants, especially on day 3 after $\mathrm{N}_{3} \mathrm{ph}-\mathrm{SO}_{3} \mathrm{H}$ treatment, exclude a release by dead or damaged cells.

Several cytoplasmic proteins, devoid of a secretory peptide signal, have been reported to be released and different alternative secretory pathways have been proposed. One hypothesis is the post-translational/translocation of proteins across the membranes of several organelles. For example, cytosolic interleukin$1 \beta$ (IL-1 $\beta$ ) is supposed to translocate within recycling endo- somes, and thus the exocytotic fusion of vesicles with the plasma membrane should deliver IL- $1 \beta$ to the milieu in a soluble form 152]. Since the secreted annexin 1 in seminal fluid is totally soluble, it could be released by such a pathway. However, in our model, $30 \%$ of extracellular annexin 1 is detected in pellets after a high-speed centrifugation, despite the presence of EGTA. This suggests that the protein is either externally bound to vesicles in a $\mathrm{Ca}^{2+}$-independent manner, or is trapped within them. Indeed, two other secretory pathways, where vesicles containing annexin 1 are released, can be suggested. First, annexin 1 has been localized in late endosomes and has been supposed to mediate inward vesiculation in multivesicular bodies [53]. In the case of a fusion between multivesicular bodies and the plasma membrane, vesicles containing annexin 1 could be released into the extracellular milieu. Secondly, in another pathway, now referred to as ectocytosis [54], evagination of the chondrocyte plasma membrane appears to be responsible for the formation of bone matrix vesicles [55] that are enriched in certain cytoplasmic proteins, including annexin 1 [56]. Such mechanisms can be proposed in our model, but, in order to explain the presence of soluble extracellular annexin 1, vesiculation of the plasma membrane would be followed by a rapid lysis of vesicles.

Using this model, we found that annexin 1 secretion is restricted to the cellular stage of the inflammation, from $12 \mathrm{~h}$ to 9 days after $\mathrm{N}_{3}$ ph-SO $\mathrm{SO}_{3} \mathrm{H}$ administration. This supports the argument that annexin 1 secretion is an induced event related to cell activation in the inflamed gut. Other studies have suggested that annexin 1 secretion and its extracellular action do not occur during all the inflammatory period and models. For instance, peritoneal inflammatory macrophages isolated from thioglycolatetreated animals do not secrete annexin 1 , even when incubated in the presence of glucocorticoids [13]. Moreover, local antiinflammatory action of annexin 1 was not observed in all the tested models, but it can depend on the major inflammatory mediators involved at the time of its administration $[22,26]$. For instance, its action in rat paw edema depends on the inflammatory agent used and is not observed during the early stage $(1 \mathrm{~h}$ after carrageenan administration) that does not involve prostaglandin production but histamine release [22].

Taken together, our data indicate that annexin 1 secretion occurs in vivo and in vitro in inflamed proximal colon. Moreover, we show that the major part of the extracellular annexin 1 $(70 \%)$ is in a soluble form. In view of the known anti-inflammatory extracellular properties of this protein, it could be suggested that it is involved in the control of the physiopathology of experimental colitis. The local action of annexin 1 could modulate either the production of icosanoids and other inflammatory mediators, or leucocyte migration. Indeed, both events are induced during the time of its in situ secretion [47, 48], but whether these are annexin-1-induced effects remains to be demonstrated.

Nathalie Vergnolle was the recipient of a grant from the Ministère de l'Enseignement Supérieur et de la Recherche Françatise. The authors thanks M. J. Fargeas, O. Morteau, H. Chap, and J. Le Bars for their skilful scientific assistance and are very grateful to the Institut National de la Recherche Agronomique for its financial support.

\section{REFERENCES}

1. Fu, J. Y., Masferrer, J. L., Seibert, K., Raz, A. \& Needleman, P. (1990) The induction and suppression of prostaglandin $\mathrm{H}_{2}$ synthase (cyclooxygenase) in human monocytes, J. Biol. Chem. 265, $16737-16740$.

2. Barnes, P. J. \& Adcock, I. (1993) Anti-inflammatory actions of steroids: molecular mechanisms, Trends Pharmacol. Sci. 14 , $436-441$. 
3. Goppelt-Struebe, M. \& Rehfeldt, W. (1992) Glucocorticoids inhibit TNF $\alpha$-induced cytosolic phospholipase $\mathrm{A}_{2}$ activity, Biochim. Biophys. Acta 1127, 163-167.

4. Nakano, T. \& Arita, H. (1990) Enhanced expression of group II phospholipase A2 gene in the tissues of endoxin shock rats and its suppression by glucocorticoid, FEBS Lett. 273, 23-26.

5. Di Rosa, M., Radomski, M., Carnuccio, R. \& Moncada, S. (1990) Glucocorticoids inhibit the induction of nitric oxide synthase in macrophages, Biochem. Biophys. Res. Commun. 172, 12461252.

6. Flower, R. J. (1988) Lipocortin and the mechanism of action of the glucocorticoids, Br. J. Pharmacol. 94, 987-1015.

7. Wallner, B. P., Mattaliano, R. J., Hession, C., Cate, R. L., Tizard, R., Sinclair, L. K., Foeller, C., Chow, E. P., Browning, J. L., Ramachandran, K. L. \& Pepinsky, R. B. (1986) Cloning and expression of human lipocortin, a phospholipase $A_{2}$ inhibitor with potential anti-inflammatory activity, Nature $320,77-81$.

8. Pepinsky, R. B., Sinclair, L. K., Browning, J. L., Mattaliano, R. J., Smart, J. E., Chow, E. P., Falbel, T., Ribolini, A., Garwin, J. L. \& Wallner, B. P. (1986) Purification and partial sequence analysis of a $37 \mathrm{kDa}$ protein that inhibits phospholipase $\mathrm{A}_{2}$ activity from rat peritoneal exudates, J. Biol. Chem. 261, 4239-4246.

9. Raynal, P. \& Pollard, H. B. (1994) Annexins: the problem of assessing the biological role for a gene family of multifunctional calcium- and phospholipid-binding proteins, Biochim. Biophys. Acta 1197, 63-93.

10. Flower, R. J. \& Rothwell, N. J. (1994) Lipocortin-1: cellular mechanisms and clinical relevance, Trends Pharmacol. Sci. 15, 71-76.

11. Perretti, M. (1994) Commentary: lipocortin-derived peptides, Biochem. Pharmacol. 47, 931-938.

12. Ambrose, M. P. \& Hunninghake, G. W. (1990) Corticosteroids increase lipocortin I in BAL fluid from normal individuals and patients with lung disease, J. Appl. Physiol. 68, 1668-1671.

13. Browning, J. L., Ward, M. P., Wallner, B. P. \& Pepinsky, R. B. (1990) Studies on the structural properties of lipocortin 1 and the regulation of its synthesis by steroids, in Progress in clinical and biological research: cytokines and lipocortins in inflammation and differentiation (Meli, M. \& Parente, L., eds) pp. 27-45, Wiley-Liss, New York.

14. Goulding, N. J., Godolphin, J. L., Sharland, P. R., Peers, S. H., Sampson, M., Maddison, P. J. \& Flower, R. J. (1990) Anti-inflammatory lipocortin 1 production by peripheral blood leucocytes in response to hydrocortisone, Lancet $335,1416-1418$.

15. Loxley, H. D., Cowel, A. M., Flower, R. J. \& Buckingham, J. C. (1993) Modulation of the hypothalamo-pituary-adrenocortical responses to cytokines in the rat by lipocortin 1 and glucocorticoids: a role for lipocortin 1 in the feedback inhibition of CRF-41 release? Neuroendocrinology 57, 801-814.

16. Solito, E., Raugei, G., Melli, M. \& Parente, L. (1991) Dexamethasone induces the expression of the mRNA of lipocortin 1 and 2 and the release of lipocortin 1 and 5 in differentiated but not in undifferenriated U-937 cells, FEBS Lett. 291, 238-244.

17. Taylor, A. D., Cowell, A. M., Flower, R. J. \& Buckingham, J. C. (1994) Lipocortin 1 mediates an early inhibitory action of glucocorticoids on the secretion of ACTH by the rat anterior pituitary gland in vitro, Neuroendocrinology 58, 430-439.

18. Cirino, G., Flower, R. J., Browning, J. L., Sinclair, L. K. \& Pepinsky, R. B. (1987) Recombinant human lipocortin inhibits thromboxane release from guinea-pig isolated perfused lung, Nature $328,270-272$.

19. Errasfa, M., Bachelet, M. \& Russo-Marie, F. (1988) Inhibition of phospholipase $\mathrm{A}_{2}$ activity of guinea-pig alveolar macrophages by lipocortin-like proteins purified from mouse lung, Biochem. Biophys. Res. Commun. 153, 1271-1275.

20. Fradin, A., Rothhut, B., Poincelot-Canton, B., Errasfa, M. \& RussoMarie, F. (1988) Inhibition of eicosanoid and PAF formation by dexamethasone in rat inflammatory polymorphonuclear neutrophils may implicate lipocortin(s), Biochim. Biophys. Acta 963, $248-257$.

21. Maridonneau-Parini, I., Errasfa, M. \& Russo-Marie, F. (1989) Inhibition of $\mathrm{O}_{2}^{-}$generation by dexamethasone is mimicked by lipocortin 1 in alveolar macrophages, J. Clin. Invest. 83, 19361940.
22. Cirino, G., Peers, S. H., Flower, R. J., Browning, J. L. \& Pepinsky, R. B. (1989) Human recombinant lipocortin 1 has acute local antiinflammatory properties in the rat paw edema test, Proc. Natl Acad. Sci. USA 86, 3428-3432.

23. Errasfa, M. \& Russo-Marie, F. (1989) A purified lipocortin shares the anti-inflammatory effect of glucocorticosteroids in vivo in mice, Br. J. Pharmacol. 97, 1051-1058.

24. Relton, J. K., Strijbos, P. J., O'Shaughnessy, C. T., Carey, F., Forder, R. A., Tilders, F. J. \& Rothwell, N. J. (1991) Lipocortin-1 is an endogenous inhibitor of ischemic damage in the rat brain, $J$. Exp. Med. 174, 305-310.

25. Becherucci, C., Perreti, M., Solito, E., Galeotti, C. L. \& Parente, L. (1993) Conceivable difference in the anti-inflammatory mechanisms of lipocortin 1 and 5, Med. Inflammation 2, 109-113.

26. Perretti, M. \& Flower, R. J. (1993) Modulation of IL-1-induced neutrophil migration by dexamethasone and lipocortin $1, J$. Immunol. 150, 992-999.

27. Pfäffle, M., Ruggiero, F., Hofmann, H., Fernandez, M. P., Selmin, O., Yamada, Y., Garrone, R. \& von der Mark, K. (1988) Biosynthesis, secretion and extracellular localization of anchorin CII, a collagen-binding protein of the calpactin family, EMBO J.7, $2335-2342$.

28. Smith, S. F., Tetley, T. D., Guz, A. \& Flower, R. J. (1990) Detection of lipocortin 1 in human lung lavage fluid: lipocortin degradation as a possible proteolytic mechanism in the control of inflammatory mediators and inflammation, Environ. Health Perspect. 85. $135-144$.

29. Christmas, P., Callaway, J., Fallon, J., Jones, J. \& Haigler, H. T. (1991) Selective secretion of annexin 1, a protein without a signal sequence, by the human prostate gland, J. Biol. Chem. 266, $2499-2507$.

30. Yeatman, T. J., Updyke, T. V., Kaetzel, M. A., Dedman, J. R. \& Nicolson, G. L. (1993) Expression of annexins on the surfaces of non-metastasic and metastasic human and rodent tumors cells, Clin. Exp. Metastasis 11, 37-44.

31. Serres, M., Coméra, C. \& Schmitt, D. (1994) Annexin 1 regulation in human epidermal cells, Cell. Mol. Biol. 40, 701-706.

32. Muesch, A., Hartmann, E., Rohde, K., Rubartelli, A., Sitia, R. \& Rapoport, T. A. (1990) A novel pathway for secretory proteins? Trends Biochem. Sci. 15, 86-88.

33. Comera, C., Rothhut, B. \& Russo-Marie, F. (1990) Identification and characterization of phospholipase $\mathrm{A}_{2}$ inhibitory proteins in human mononuclear cells, Eur. J. Biochem. 188, 139-146.

34. Parente, L., Becherucci, C., Peretti, M., Solito, E., Mugridge, K. G., Galeotti, C., Raugei, G., Melli, M. \& Sanso, M. (1990) Are the lipocortins the second messengers of the anti-inflammatory action of glucocorticoids? in Progress in clinical and biological research: cytokines and lipocortins in inflammation and differentiation (Meli, M. \& Parente, L., eds) pp. 55-68, Wiley-Liss, New York.

35. Elderfield, A. J., Newcombe, J., Bolton, C. \& Flower, R. J. (1992) Lipocortins (annexins) 1, 2, 4 and 5 are increased in the central nervous system in multiple sclerosis, J. Neuroimmunol. 39, 91100.

36. Bastian, B. C., van der Piepen, U., Römisch, J., Pâques, E. P. \& Bröcker, E. B. (1993) Localization of annexins in normal and diseased human skin, J. Dermatol. Sci. 6, 225-234.

37. Mullens, L., Marriott, D. R., Youing, K. A., Tannahill, L., Lightman, S. L. \& Wilkin, G. P. (1994) Up-regulation of lipocortin-1 and its mRNA in reactive astrocytes in kainate-lesioned rat cerebellum, J. Neuroimmunol. 50, 25-33.

38. Sakanoue, Y., Horai, T., Okamato, T., Hatada, T., Shoji, Y., Futija, S., Kusunoki, M. \& Utsunomiya, J. (1992) Lipocortin-present perforating and lipocortin-absent nonperforating Crohn's disease, Am. J. Surg. 164, 341-344.

39. Morris, G. P., Beck, P. L., Herridge, M. S., Depew, W. T., Szewczuk, M. R. \& Wallace, J. L. (1989) Hapten-induced model of chronic inflammation and ulceration in the rat colon, Gastroenterology 96, 795-803.

40. Bradford, M. (1976) A rapid and sensitive method for the quantification of microgram quantities of protein utilizing the principe of protein-dye binding, Anal. Biochem. 72, 248-254.

41. Laemmli, U. K. (1970) Cleavage of structural proteins during the assembly to the head of bacteriophage T4, Nature $227,680-685$. 
42. Towbin, H., Staehelin, T. \& Gordon, J. (1979) Electrophoretic transfer of proteins from polyacrylamide gels to nitrocellulose sheets: procedure and some applications, Proc. Natl Acad. Sci. USA 76, 4350-4354.

43. Bergmeyer, H. U. \& Bernt, E. (1974) Lactate dehydrogenase: UVassay with pyruvate and NADH, in Methods of enzymatic analysis (Bergmeyer, U. H., ed.) vol. 2, pp. 574-579, Academic Press New York.

44. Bradley, P., Priebat, D. A., Christensen, R. D. \& Rothstein, G. (1982) Measurement of cutaneous inflammation: estimation of neutrophil content with an enzyme marker, J. Invest. Dermatol. $78,206-209$.

45. Smith, J. W. \& Castro, G. A. (1978) Relation of peroxidase activity in gut mucosa to inflammation, Am. $J$. Physiol. 234, R72R79.

46. Vishwanath, B. S., Frey, F. J., Bradbury, M., Dallman, M. F. \& Frey, B. M. (1992) Adrenalectomy decreases lipocortin-I messenger ribonucleic acid and tissue protein content in rats, Endocrinology $130,585-591$.

47. Eliakim, R., Karmeli, F., Okon, E. \& Rachmilewitz, D. (1992) Ketotifen effectively prevents mucosal damage in experimental colitis, Gut 33, 1498-1503.

48. Allgayer, H., Deschryver, K. \& Stenson, W. F. (1989) Treatment with $16-16^{\prime}$-dimethyl prostaglandin $\mathrm{E} 2$ before and after induction of colitis with trinitrobenzenesulfonic acid in rats decreases inflammation, Gastroenterology 96, 1290-1300.
49. Coméra, C., Rothhut, B., Cavadore, J. C., Vilgrain, I., Cochet, C., Chambaz, E. \& Russo-Marie, F. (1989) Futher characterization of four lipocortins from human peripheral blood mononuclear cells, J. Cell. Biochem. 40, 361-370.

50. Meers, P., Mealy, T., Pavlotsky, N. \& Tauber, A. I. (1992) Annexin 1-mediated vesicular aggregation: mechanism and role in human neutrophils, Biochemistry 31, 6372-6382.

51. Lecabec, V. \& Maridonneau-Parini, I. (1994) Annexin 3 is associated with cytosolic granules in neutrophils and monocytes and translocates to plasma membrane in activated cells, Biochem. $J$. $303,481-488$

52. Rubartelli, A. \& Sitia, R. (1991) Interleukin $1 \beta$ and thioredoxin are secreted through a novel pathway of secretion, Biochem. Soc. Trans. 19, 255-259.

53. Futter, C. E., Feder, S., Schlessinger, J., Ullrich, A. \& Hopkins, C. $R$. (1993) Annexin 1 is phosphorylated in the multivesicular body during the processing of the epidermal growth factor receptor, $J$. Cell. Biol. 120, 77-83.

54. Stein, J. M. \& Luzio, J. P. (1991) Ectocytosis caused by sublytic autologous complement attack on human neutrophils, Biochem. $J$. $274,381-386$.

55. Hale, J. E. \& Wuthier, R. E. (1987) The mechanism of matrix vesicle formation, J. Biol. Chem. 262, 1916-1925.

56. Genge, B. R., Wu, L. N. Y. \& Wuthier, R. E. (1989) Identification of phospholipid dependent calcium binding proteins as constituents of matrix vesicles, J. Biol. Chem. 264, 1917-1921. 